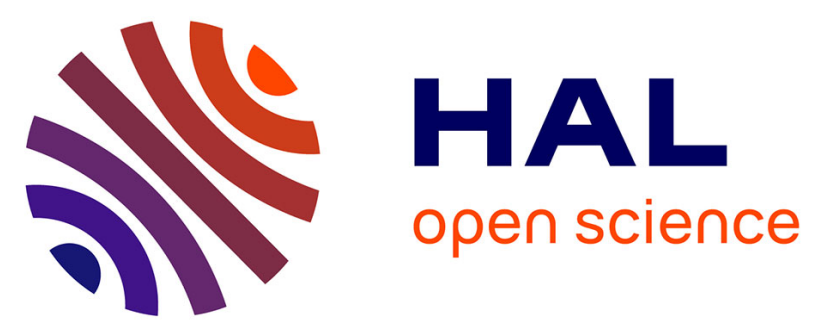

\title{
Temperature and nutrients as drivers of microbially mediated arsenic oxidation and removal from acid mine drainage
}

Vincent Tardy, Corinne Casiot, Lidia Fernandez-Rojo, Eleonore Resongles, Angélique Desoeuvre, Catherine Joulian, Fabienne Battaglia-Brunet, Marina Hery

\section{To cite this version:}

Vincent Tardy, Corinne Casiot, Lidia Fernandez-Rojo, Eleonore Resongles, Angélique Desoeuvre, et al.. Temperature and nutrients as drivers of microbially mediated arsenic oxidation and removal from acid mine drainage. Applied Microbiology and Biotechnology, 2018, 102 (5), pp.2413-2424. 10.1007/s00253-017-8716-4 . hal-02110146

\section{HAL Id: hal-02110146 \\ https://hal.umontpellier.fr/hal-02110146}

Submitted on 28 May 2021

HAL is a multi-disciplinary open access archive for the deposit and dissemination of scientific research documents, whether they are published or not. The documents may come from teaching and research institutions in France or abroad, or from public or private research centers.
L'archive ouverte pluridisciplinaire HAL, est destinée au dépôt et à la diffusion de documents scientifiques de niveau recherche, publiés ou non, émanant des établissements d'enseignement et de recherche français ou étrangers, des laboratoires publics ou privés. 


\section{Temperature and nutrients as drivers of microbially mediated arsenic oxidation and removal from Acid Mine Drainage}

Vincent Tardy ${ }^{1}$, Corinne Casiot $^{1}$, Lidia Fernandez-Rojo ${ }^{1}$, Eléonore Resongles ${ }^{1}$, Angélique Desoeuvre ${ }^{1}$, Catherine Joulian $^{2}$, Fabienne Battaglia-Brunet ${ }^{2}$ and Marina Héry ${ }^{1 \not}$

${ }^{1}$ Laboratoire HydroSciences Montpellier, UMR 5569, Montpellier, France

${ }^{2}$ BRGM, Water, Environment and Ecotechnology Division, Environmental Biogeochmistry and Water Quality Unit, Orléans, France

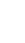

Unit, Orléans, France

(1)

Correspondence: Marina Héry, laboratoire HydroSciences Montpellier, UMR 5569, CC 57, 163 rue Auguste Broussonet, 34990, Montpellier, France

Email: marina.hery@umontpellier.fr

9

20


Abstract

Microbial oxidation of iron $(\mathrm{Fe})$ and arsenic (As) followed by their co-precipitation lead to the natural attenuation of these elements in As-rich Acid Mine Drainage (AMD). The parameters driving the activity and diversity of bacterial communities responsible for this mitigation remain poorly understood. We conducted batch experiments to investigate the effect of temperature ( $20 \mathrm{vs} 35^{\circ} \mathrm{C}$ ) and nutrient supply on the rate of $\mathrm{Fe}$ and As oxidation and precipitation, the bacterial diversity (high-throughput sequencing of 16S rRNA gene) and the As oxidation potential (quantification of aioA gene) in AMD from the Carnoulès mine (France). In batch incubated at $20^{\circ} \mathrm{C}$, the dominance of iron-oxidizing bacteria related to Gallionella spp. was associated with almost complete iron oxidation (98\%). However, negligible As oxidation led to the formation of As(III)-rich precipitates. Incubation at $35^{\circ} \mathrm{C}$ and nutrient supply both stimulated As oxidation (71-75\%), linked to a higher abundance of aioA gene and the dominance of As-oxidizing bacteria related to Thiomonas spp. As a consequence, As(V)-rich precipitates (7098\% of total As) were produced. Our results highlight strong links between indigenous bacterial community composition and iron and arsenic removal efficiency within AMD, and provide new insights for the future development of a biological treatment of As-rich AMD.

Keywords: Acid Mine Drainage, arsenic and iron oxidation, bacterial community, temperature, nutrient. 


\section{Introduction}

Arsenic (As) is one of the most toxic pollutants commonly associated with mine tailings and Acid Mine Drainage (AMD) with concentration in mine waters ranging from $<1 \mu \mathrm{g} \mathrm{l}^{-1}$ to hundreds of $\mathrm{mg} \mathrm{l}^{-1}$ (Casiot et al. 2003a; Cheng et al. 2009). Because of the severe toxicological effects of As, contaminated waters represent a serious threat for ecosystems located downstream from mining sites and for public health. Numerous studies have reported natural attenuation of arsenic pollution in different AMD across the world (Fukushi et al. 2003; Asta et al. 2010; Egal et al. 2010). The exploitation of the microbially mediated processes involved in this attenuation represents a promising strategy for the development of treatment of As-rich AMD (Johnson and Hallberg 2005).

Natural attenuation involves biological oxidation of ferrous iron (Fe(II)) to ferric iron (Fe(III)) and the subsequent adsorption of As onto the newly formed Fe(III) precipitates or its co-precipitation (Paikaray 2015; Ahoranta et al. 2016). Efficiency of arsenic removal from AMD depends on its redox speciation. Indeed, under acid $\mathrm{pH}$, arsenate $(\mathrm{As}(\mathrm{V}))$ is more efficiently trapped onto iron phases than arsenite (As(III)) (Hug and Leupin 2003). In the environment, As(III) oxidation to As(V) is mainly catalyzed by microbial activity, chemical oxidation being generally very slow (Campbell and Nordstrom, 2014). Therefore, the ability of indigenous bacterial populations to oxidize As(III) largely contributes, together with the activity of iron-oxidizing bacteria (FeOB), to a sustainable arsenic pollution mitigation in AMD. FeOB and As(III)-oxidizing bacteria (AsOB) have been isolated from AMD and their metabolic capacities were investigated (Battaglia-Brunet et al. 2002; Duquesne et al. 2003; Bruneel et al. 2003; Casiot et al. 2003b; Egal et al. 2010). However, the factors driving the activity and diversity of indigenous complex populations of $\mathrm{FeOB}$ and $\mathrm{AsOB}$ involved in arsenic mitigation remain poorly understood.

Acidithiobacillus ferroxydans, a $\mathrm{FeOB}$ associated with attenuation process in $\mathrm{AMD}$, is a strict chemolithoautotroph bacterium (Duquesne et al. 2003; Johnson and Hallberg 2005; Egal et al. 2009). Conversely, AsOB can grow heterotrophically or autotrophically (Santini et al. 2000; Battaglia-Brunet et al. 2006; GarciaDominguez et al. 2008). In particular, Thiomonas spp. are facultative chemolithoautotrophs that grow optimally in mixotrophic media containing reduced inorganic sulfur compounds and organic supplements (Kelly et al. 2007; Bryan et al. 2009; Slyemi et al. 2011). Thus, nutrient supply in AMD is expected to have a contrasted incidence on pollution mitigation depending on the metabolic feature of the bacterial populations involved. Temperature is another primary factor governing activity and diversity of bacterial community inhabiting AMD (Méndez-García et al. 2015). Previous work on FeOB and AsOB bacterial strains isolated from diverse polluted environments showed that their growth and their oxidation activities were temperature dependent (Battaglia-Brunet et al. 2002; Dopson et al. 2006; Kim et al. 2008; Ito et al. 2012). Furthermore, temperature variation was suggested as a driving factor shaping bacterial communities structure in AMD (Volant et al. 2014). Recently, Debiec and colleagues (2017) showed that both nutrient concentration and temperature were key factors controlling the growth and the oxidation rate of Sinorhizobium sp. M14, an AsOB isolated from neutral gold mine waters. Under batch conditions, a temperature increase (from 10 to 23 or $30^{\circ} \mathrm{C}$ ) resulted in the stimulation of bacterial growth associated with a faster As(III) oxidation rate. Under continuous conditions, a supply of yeast extract stimulated both the growth and the As(III) oxidation activity of Sinorhizobium sp. M14 (Debiec et al. 2017). Whether or not such studies based on a single strain may be extrapolated to a metabolically and taxonomically diverse indigenous community has not been explored so far. In this context, the aim of the present study was to assess the influence of temperature 
83 and nutrients on the diversity of an indigenous AMD bacterial community and on its efficiency for iron and arsenic oxidation and removal from water.

For this purpose, we conducted batch experiments with As-rich AMD water of Carnoulès mine (Southern France) incubated either at $20^{\circ} \mathrm{C}$ or $35^{\circ} \mathrm{C}$ and supplied or not with yeast extract. Iron and arsenic speciation was monitored in the dissolved phase and in the biogenic precipitates that formed during batch incubation. Diversity of bacterial community was characterized by high-throughput sequencing of 16S rRNA genes and the genetic potential for arsenic oxidation was evaluated by the quantification of aioA genes. 


\section{Materials and methods}

\section{Water sampling and batch experiment setup}

Water was collected in June 2015 from the source of Reigous creek at the abandoned Carnoulès mine

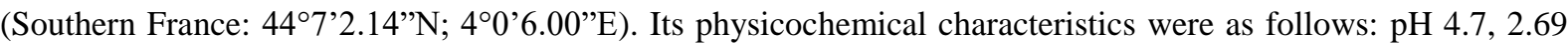
$\mathrm{mg} \mathrm{O}_{2} \mathrm{l}^{-1}, 14.9^{\circ} \mathrm{C}, 2.56 \mathrm{mS} \mathrm{cm}{ }^{-1}, 590.6 \mathrm{mV}, 511 \mathrm{mg} \mathrm{Fe}^{-1}(100 \% \mathrm{Fe}(\mathrm{II})), 53.8 \mathrm{mg} \mathrm{As}^{-1}(14 \% \mathrm{As}(\mathrm{V}))$.

Batch experiment was setup within six hours of water collection by transferring $450 \mathrm{ml}$ of water in 1 liter Schott Duran ${ }^{\circledR}$ bottles, previously acid-cleaned and autoclaved. Two conditions were tested: biotic (water with indigenous microbial communities) and abiotic (sterile-filtered water with $0.22 \mu \mathrm{m}$ cellulose acetate filter). For each condition, four treatments (“T”) were applied: (i) $20^{\circ} \mathrm{C}$ without nutrient supply ("T20”), (ii) $35^{\circ} \mathrm{C}$ without nutrient supply (“T35”), (iii) $20^{\circ} \mathrm{C}$ with nutrient supply (“T20Y”), and (iv) $35^{\circ} \mathrm{C}$ with nutrient supply ("T35Y"). Nutrient supply consisted of spiking water with yeast extract at a final concentration of $0.2 \mathrm{~g} \mathrm{l}^{-1}$. This concentration is typically used in culture media for the heterotrophic growth of AsOB like Thiomonas spp. (Battaglia-Brunet et al. 2002; 2006). A total of 12 biotic batch experiments (four treatments, three replicates) and eight abiotic batch experiments (four treatments, two replicates) were set up. All batch were closed with cellulose stoppers to prevent bacterial contamination from outside and to allow oxygen diffusion inside the batch. Batch were placed under orbital agitation at $150 \mathrm{rpm}$ in thermo-regulated chambers to assure water aeration and a constant temperature (set up at $20^{\circ} \mathrm{C}$ or $35^{\circ} \mathrm{C}$ ) throughout the experiment duration.

\section{Batch experiment monitoring}

The experiment was conducted for eight days. Water samples $(\sim 3 \mathrm{ml})$ were collected from the bottles for chemical analysis at days $0,2,3,4,5,6,7$ and 8 . At day 3,5 and 8, pH and dissolved oxygen were measured with a multiparameter analyser (Ultrameter ${ }^{\mathrm{TM}}$ Model 6P). Dissolved oxygen remained stable, with an average of $7.8 \pm$ $0.5 \mathrm{mg} \mathrm{O}_{2} \mathrm{l}^{-1}$ in all batch (data not shown). $\mathrm{pH}$ decreased during incubation from 4.7 to $2.7 \pm 0.2$ and $3.6 \pm 0.1$ in the biotic and abiotic experiments respectively (data not shown), in relation with Fe(II) oxidation and subsequent Fe(III) hydrolysis (Nordstrom and Alpers 1999). After sampling, water was immediately filtered through disposable filters (cellulose acetate, pore size $0.22 \mu \mathrm{m}$ ) and the filtrate was analyzed for $\mathrm{Fe}(\mathrm{II})$, total $\mathrm{Fe}, \mathrm{As}(\mathrm{III})$ and $\mathrm{As}(\mathrm{V})$ concentration according to routine procedures described in Fernandez-Rojo et al. (2017).

At the end of the experiment, batch were sacrificed. After homogenization of liquid and solid phases (including biogenic precipitates that formed during the incubation in biotic batch), a subsample (100 ml) was filtered on sterile $0.22 \mu \mathrm{m}$ cellulose acetate filters. The filters were stored at $-80^{\circ} \mathrm{C}$ before DNA extraction. Another subsample $(3 \mathrm{ml})$ was collected for biomass quantification by flow cytometry. At last, the remaining batch content $(\sim 300-350 \mathrm{ml})$ was filtrated using $0.22 \mu \mathrm{m}$ cellulose acetate filter for quantification of total iron and arsenic species $(\mathrm{As}(\mathrm{III})$ and $(\mathrm{V}))$ in the particulate fractions. The filter was placed in a vacuum desiccator, dried until constant weight and a chemical extraction with orthophosphoric acid was performed as described in Resongles et al. (2016).

\section{Chemical analyses}

Total dissolved $\mathrm{Fe}$ and $\mathrm{Fe}(\mathrm{II})$ concentrations were determined with a spectrophotometer (SECOMAN S250, detection limit $=88 \mu \mathrm{g} \mathrm{l}^{-1}$, uncertainty $= \pm 5 \%$ ) at $510 \mathrm{~nm}$ wavelength (Rodier 1996). For As speciation analysis in the dissolved phase and precipitate extracts, samples were analyzed with HPLC (High Performance 
Liquid Chromatography) using an anion exchange column ( $25 \mathrm{~cm} \times 4.1 \mathrm{~mm}$ i.d. Hamilton PRP-X100) coupled to ICP-MS (PQ2+, X Series, Thermo; Detection limit $=0.2 \mu \mathrm{g} \mathrm{l}^{-1}$ for As(III), $0.4 \mu \mathrm{g} \mathrm{l}^{-1}$ for As(V), uncertainty $= \pm 5$ \%) (Héry et al. 2014; Resongles et al. 2016). The Certified Reference Water NIST1643e was used to check the analytical accuracy for total As concentration and the RSD was always lower than $5 \%$ with respect to the certified value.

The proportion of arsenic oxidized after the eight-day incubation period was calculated using the following equation:

$A s(I I I)$ oxidized $=\frac{\left(A s(I I I)_{d} t^{0}+A s(I I I)_{p} t^{0}\right)-\left(A s(I I I)_{d} t^{f i n a l}+A s(I I I)_{p} t^{f^{\text {inal }}}\right)}{\left(A s(I I I)_{d} t^{0}+A s(I I I)_{p} t^{0}\right)} \times 100$

where $\mathrm{As}(\mathrm{III})_{\mathrm{d}}$ and $\mathrm{As}(\mathrm{III})_{\mathrm{p}}$ were the concentration of dissolved and particulate $\mathrm{As}(\mathrm{III})$ (in $\mathrm{mg} \mathrm{l}^{-1}$ ), respectively, at the beginning of experiment $\left(\mathrm{t}^{0}\right)$ or after 8 days of incubation $\left(\mathrm{f}^{\mathrm{final}}\right)$.

\section{Biomass quantification}

Quantification of bacterial biomass from samples (water and precipitate) was performed by flow cytometric counting method. Prior analysis, bacterial cells were detached from mineral biogenic precipitates according to the procedure of Lunau et al. (2005), with some modifications. Briefly, methanol 100\% was added to water sample to reach a final concentration of $10 \%$ and incubated $15 \mathrm{~min}$ in an ultrasonic bath (42 kHz). Detrital and inorganic particles were removed by a low centrifugation $(1 \mathrm{~min}$ at $190 \times g)$ and supernatant was recovered in nine volumes of sterile Milli-Q ${ }^{\circledR}$ water. Then, bacterial cells were pooled by centrifugation at $6500 \times g$ for $10 \mathrm{~min}$, washed in Milli-Q ${ }^{\circledR}$ water and stained 15 min in the dark with the LIVE/DEAD BacLight bacterial viability kit (Invitogen, Carlsbad, CA, USA). Bacterial cells abundance was measured with a Gallios ${ }^{\mathrm{TM}}$ flow cytometer (Beckman Coulter, Brea, CA). Live and dead bacterial cells were detected at $520 \mathrm{~nm}$ and $630 \mathrm{~nm}$, respectively. More than 20,000 analytical events were counted in triplicate for each sample and data analysis was processed with Kaluza software (Beckman Coulter). Since the numbers of live and dead bacteria were in the same order of magnitude in all the samples, only the total bacteria cells (i.e. live + dead bacteria) are presented.

\section{DNA extraction and quantification}

For each biotic treatment, DNA was extracted from $100 \mathrm{ml}$ of homogenised and filtered batch content (as described in 2.2) using the Powerwater DNA Isolation Kit according to the manufacturer's recommendations (MoBio Laboratories Inc., Carlsbad, CA, USA). DNA was quantified with a fluorometer (Qubit ${ }^{\circledR}$, Invitrogen) and stored at $-20^{\circ} \mathrm{C}$ until further analysis.

\section{Quantification of aioA genes}

The abundance aioA genes encoding the catalytic subunit of the As(III)-oxidase was determined by quantitative real-time PCR (qPCR). The reverse primers aoxBM2-1R and forward primer aoxBM4-1F were used to target a $110 \mathrm{bp}$ fragment of the aioA gene (Quéméneur et al. 2010). For each sample, 2 ng of DNA were used in a $20 \mu \mathrm{l}$ PCR reaction with $0.3 \mu \mathrm{M}$ of each primer, $100 \mathrm{ng}$ of T4GP32 (MP Biomedicals) and 1X IQ SYBR Green Supermix (BioRad). The program was run in a CFX Connect (BioRad) and consisted in an initial denaturation at $95{ }^{\circ} \mathrm{C}$ for $3 \mathrm{~min}$, followed by 40 cycles of $95^{\circ} \mathrm{C}$ for $10 \mathrm{~s}, 54^{\circ} \mathrm{C}$ for $20 \mathrm{~s}, 72{ }^{\circ} \mathrm{C}$ for $10 \mathrm{~s}$, and a data 
acquisition step at $80{ }^{\circ} \mathrm{C}$ for $10 \mathrm{~s}$. At the end, a melting curve analysis was performed through measurement of the SYBR Green I signal intensities during a $0.5^{\circ} \mathrm{C}$ temperature increment every $10 \mathrm{~s}$ from $65^{\circ} \mathrm{C}$ to $95^{\circ} \mathrm{C}$.

\section{Sequencing of 16S rRNA gene}

Bacterial diversity was determined by Illumina high-throughput sequencing of bacterial 16S rRNA genes. V4-V5 region (about 450 bases) was amplified by PCR using primers PCR1_515F (Barret et al. 2015) and PCR1_928R (Wang and Qian 2009). For each sample, $10 \mathrm{ng}$ of DNA were used in a $50 \mu 1$ PCR reaction conducted under the following conditions: $94^{\circ} \mathrm{C}$ for $2 \mathrm{~min}, 30$ cycles of $1 \mathrm{~min}$ at $94^{\circ} \mathrm{C}, 65^{\circ} \mathrm{C}$ for $40 \mathrm{~s}$ and $72^{\circ} \mathrm{C}$ for $30 \mathrm{sec}$, followed by $10 \mathrm{~min}$ at $72^{\circ} \mathrm{C}$. The PCR products were checked by gel electrophoresis and quantified using a fluorometer (Qubit®, Invitrogen) and sent to GeT-PlaGe platform (Toulouse, France) for Illumina MiSeq analysis using a $2 \times 300$ bp protocol.

\section{Bioinformatic analyses of 16S rRNA gene sequences}

Raw sequence reads were merged into full-length sequences by FLASH v1.2.11 (Magoc and Salzberg 2011). Reads were further processed using the software program MOTHUR version 1.31 (Schloss et al. 2009). Firstly, raw sequences were selected based on the following criteria: (i) length (between 350 and $460 \mathrm{bp}$ ), (ii) homopolymer lengths $(<7)$ and (iii) the absence of ambiguous bases. Then, sequences were aligned against the SILVA reference database (Release 123) and removed when they did not align correctly. Chimeric sequences were detected and removed using the implementation of Chimera UCHIME (Edgar et al. 2011). A further screening step (pre-cluster) was applied to reduce sequencing noise by clustering reads differing by only one base every 100 bases. Taxonomic affiliation of 16S rRNA genes was performed with a Bayesian classifier (Wang et al. 2007) ( $80 \%$ bootstrap confidence score) against the SILVA reference database. In order to efficiently compare the datasets and avoid biased community comparisons, the sample reads were reduced to the lowest datasets by random selection (4353 reads). The remaining high quality sequences were used to generate a distance matrix and clustered into Operational Taxonomic Units (OTUs) defined at 97\% cutoff using the average neighbor algorithm. OTUbased diversity indices, rarefaction curves and Unifrac distance were calculated with MOTHUR at a level of 97\% sequence similarity. The raw datasets are available on the European Nucleotide Archive system under project accession number PRJEB21683.

\section{Statistical analysis}

The statistical significance of the bacterial biomass increase during batch incubations was assessed with the nonparametric Kruskall-Wallis test. Physicochemical parameters, oxidation rates, diversity metric and aioA genes quantification obtained for the biotic treatments were compared by two-way ANOVA and the differences between them analyzed with a Fisher test $(\mathrm{P}<0.05)$. Differences in bacterial community structure between biotic treatments were characterized using UniFrac distance (Lozupone and Knight 2005). Non Metric Multidimensional Scaling (NMDS) was used to graphically depict differences between the bacterial communities. The significance of the observed clustering of samples on the ordination plot was assessed by an ANalysis Of SIMilarity (ANOSIM, 999 permutations). All these statistical analyses were performed with the R free software (http://www.rproject.org/). 


\section{Results}

\section{Bacterial biomass}

Bacterial biomass initially present in the water collected at the Reigous spring was $1.4 \pm 0.8 \times 10^{4}$ bacterial cells $\mathrm{ml}^{-1}$. After 8 days of incubation in biotic batch, bacterial cell concentration increased from 1 to 3 order of magnitude depending on the treatment applied (T20 $\approx \mathrm{T} 35<\mathrm{T} 35 \mathrm{Y}<\mathrm{T} 20 \mathrm{Y})$ (Fig. 1). In abiotic batch, small particles that most probably corresponded to Fe colloids induced a background noise ranging from $2.6 \times 10^{3}$ to 1.8 $\times 10^{4}$ particles $\mathrm{ml}^{-1}$.

\section{Evolution of dissolved Fe(II), dissolved As(III) and precipitated Fe concentrations}

In the biotic batch experiments, the concentration of dissolved Fe(II) and As(III) decreased substantially over time (Fig. 2A and 2B). In batch incubated at $20^{\circ} \mathrm{C}$ without nutrient (T20), Fe(II) concentration decreased gradually from $516 \mathrm{mg} \mathrm{l}^{-1}$ to $20 \mathrm{mg} \mathrm{l}^{-1}$. At $35^{\circ} \mathrm{C}$ without nutrients (T35), $\mathrm{Fe}(\mathrm{II})$ concentration decreased more rapidly during the first 5 days of incubation, and then remained stable $\left(136 \mathrm{mg} \mathrm{l}^{-1}\right)$. At $20^{\circ} \mathrm{C}$ with nutrients (T20Y), there was only a slight decrease of $\mathrm{Fe}(\mathrm{II})$ throughout time, with a final concentration of $393 \mathrm{mg} 1^{-1}$. At $35^{\circ} \mathrm{C}$ with nutrient supply (T35Y), the decrease of Fe(II) concentration was delayed; however, a drastic decrease occurred between day 5 and day 7 , reaching a final concentration of $7 \mathrm{mg} \mathrm{l}^{-1}$ of $\mathrm{Fe}$ (II) (Fig. 2A).

Nutrient supply and higher temperature (T20Y, T35 and T35Y) induced a stronger decrease of As(III) concentration compared to the $20^{\circ} \mathrm{C}$ treatment (T20) in the biotic batch experiments (Fig. 2B). The combination of higher temperature and nutrient supply (T35Y) resulted in a fast and complete removal of As(III) after only three days. Complete removal of As(III) was also achieved after 7 days in biotic batch incubated at $35^{\circ} \mathrm{C}$ without nutrients (T35) and in biotic batch incubated at $20^{\circ} \mathrm{C}$ with nutrients (T20Y). In the T20 batch, only $67 \%$ of the As(III) was removed from the dissolved phase in 8 days (Fig. 2B).

Under biotic conditions, the decrease of the dissolved Fe(II) concentration was closely related to $\mathrm{Fe}$ precipitation. Consistent trends were observed for the two curves in the different batch experiments (Fig. 2A and C). Slight differences between dissolved Fe(II) loss and precipitated Fe can be explained by the presence of few dissolved Fe(III).

In abiotic batch experiments, the concentration of dissolved Fe(II) and As(III) decreased no more than $0.6 \%$ and $19 \%$ respectively (Fig. $2 \mathrm{~A}$ and B).

\section{Iron and arsenic species in the particulate phase}

The amount of precipitates formed after eight days under biotic conditions was 4- to 11- fold higher than under abiotic conditions (Table 1). In these biogenic precipitates, the $\mathrm{As} / \mathrm{Fe}$ and $\mathrm{As}(\mathrm{III}) / \mathrm{As}(\mathrm{V})$ ratios showed wide variations depending on the treatments applied compared to narrow variations observed in the particles formed abiotically (Table 1). Nutrient-amended biotic batch incubated at $20^{\circ} \mathrm{C}$ (T20Y) exhibited a significantly higher $\mathrm{As} / \mathrm{Fe}$ ratio (0.60) than the other treatments $(\mathrm{As} / \mathrm{Fe} \leq 0.23)$, which is consistent with the limited iron oxidation and precipitation observed in these batch (Fig. 2A and 2C). In T20 batch, the particulate phase was As(III)-rich $(\mathrm{As}(\mathrm{III}) / \mathrm{As}(\mathrm{V})$ ratio $=6.48)$ suggesting that the decrease of dissolved As(III) (Fig. 2B) was not due to its oxidation. Conversely in $\mathrm{T} 20 \mathrm{Y}, \mathrm{T} 35, \mathrm{~T} 35 \mathrm{Y}$ batch experiments, the biogenic precipitates were $\mathrm{As}(\mathrm{V})$-rich (average 
$\mathrm{As}(\mathrm{III}) / \mathrm{As}(\mathrm{V})$ ratio $\leq 0.43)$. For these treatments, the decrease of dissolved As(III) observed (Fig. 2B) may then be linked to a possible As(III) oxidation. The T35Y treatment resulted in the formation of the biogenic precipitate the more enriched in $\mathrm{As}(\mathrm{V})(\mathrm{As}(\mathrm{III}) / \mathrm{As}(\mathrm{V})$ ratio= 0.02).

\section{Iron and arsenic oxidation}

The proportion of iron and arsenic oxidized during the incubation was calculated based on the concentration of dissolved and particulate arsenic and iron species at the beginning and at the end of experiment (Fig. 3). Under abiotic conditions, iron oxidation was negligible and As(III) oxidation did not exceed $6 \%$. Under biotic conditions, the lowest proportion of Fe(II) oxidized was observed for the T20Y treatment (24\%). No biological As(III) oxidation was observed in T20 batch experiments. Conversely, the proportion of As(III) oxidized exceeded 70\% in the others treatments (T20Y, T35 and T35Y) (Fig. 3). The highest proportion of As(III) oxidized was obtained in nutrient supplied batch incubated at $35^{\circ} \mathrm{C}(98 \%)$.

\section{Diversity of bacterial communities}

High-throughput sequencing yielded a total of 119,065 sequences of 16S-rRNA gene corresponding to 4353 quality sequences per sample which adequately covered the bacterial diversity in all the experiments (Table 2 and Fig. S1). For all the treatments, the bacterial diversity indices (Richness, Evenness and Shannon) decreased significantly after incubation compared to the initial water collected at the Reigous spring. The batch incubated at $20^{\circ} \mathrm{C}$ without nutrients (T20) exhibited the lower level of bacterial diversity. The higher richness was observed in the batch incubated at $35^{\circ} \mathrm{C}$ (Table 2).

NMDS analysis of the full bacterial-sequences datasets (Fig. 4) highlighted the establishment of distinct bacterial community structures at the end of the batch experiments. ANOSIM test confirmed that the genetic structures of the communities were significantly different $(\mathrm{R}=0.988, \mathrm{P}=0.001)$. These differences were associated with different taxonomic compositions (Fig. 5). In agreement with the diversity indices, bacterial communities for all the treatments (T20, T20Y, T35 and T35Y) were characterized by the dominance of a small number of OTUs. In the batch incubated at $20^{\circ} \mathrm{C}$ (T20), bacterial community was dominated by a single OTU affiliated to the Gallionella genus representing an average of $82 \%$ of total sequences. Incubation at $35^{\circ} \mathrm{C}$ led to the emergence of a dominant OTU affiliated to Thiomonas genus (49 to 79\%), and to a lesser extent, to Ferritrophicum genus (5 to 9\%). The supply of yeast extract in batch incubated at $20^{\circ} \mathrm{C}$ mainly favored the development of bacteria related to genera Acidocella (47 to $55 \%$ ), Thiomonas (7 to 14\%) and Gallionella (8 to 10\%). Finally, bacterial community in the nutrient amended-batch incubated at $35^{\circ} \mathrm{C}$ was dominated by OTUs affiliated to Acidicapsa (13 to 55\%), Gallionella (17 to 23\%), Thiomonas (11 to 14\%), Acidocella (0 to 24\%) and Ferritrophicum (3 to 6\%). The bacterial groups that dominated at the end of the batch experiments represented no more than 10 to $20 \%$ of the initial community of the Reigous spring water used in these experiments.

Batch incubations resulted in an enrichment in bacteria with the genetic potential for As(III) oxidation as revealed by the quantification of aioA genes (Fig. 6). Nutrient supply or incubation at $35^{\circ} \mathrm{C}$ resulted in a one or two order of magnitude higher abundance of aioA genes (representing on average $5 \pm 1 \times 10^{5}, 2 \pm 1 \times 10^{6}, 4 \pm 5 \times$ $10^{5}$ genes copies per ng of DNA for T20Y, T35 and T35Y, respectively) compared to the batch incubated at $20^{\circ} \mathrm{C}$ 
$271\left(1.4 \pm 0.4 \times 10^{4}\right.$ genes copies per ng of DNA) and to the initial water $\left(4 \pm 2 \times 10^{3}\right.$ genes copies per ng of DNA $\left.{ }^{-1}\right)$.

272 The highest number of aioA gene copies was obtained as a consequence of the incubation at $35^{\circ} \mathrm{C}$. 


\section{Discussion}

We investigated the role of temperature and nutrients as drivers of the microbially mediated removal of iron and arsenic in an As-rich AMD. We confirmed that indigenous microbial communities through their capacity to oxidize iron and arsenic are the actors of the mitigation of the pollution in AMD (Casiot et al. 2003b; Egal et al. 2010; Mitsunobu et al. 2013). Abiotic oxidation and removal of iron and arsenic remained very limited without microbial catalysis and were not influenced by nutrient supply or temperature increase.

\section{Bacterial diversity in AMD water and its evolution in batch experiments}

The initial bacterial diversity in the Carnoulès AMD water was similar to those previously described by Volant and colleagues (2014). Batch incubations resulted in the decrease of diversity associated with the preferential development of specific bacterial taxa. This can be explained by the inability of some microorganisms to thrive under laboratory conditions (Koskella and Vos 2015), and by the strong competitiveness of other microorganisms (Hibbing et al., 2010; Puspita et al., 2012). The reduction of diversity was moderated in batch supplied with nutrients and in batch incubated at $35^{\circ} \mathrm{C}$. We can hypothesize that a nutrient supply or a temperature increase led to a diversification of bacterial niches (Hibbing et al. 2010; Koskella and Vos 2015; Okie et al. 2015), promoting the co-existence of a greater number of taxa.

The incubation of AMD water under contrasted conditions of temperature and nutrient status led to the establishment of distinct bacterial communities (in terms of diversity, taxonomic composition and functional potential for As-oxidizing activity). These results confirm the influence of temperature and nutrients $(\mathrm{C}, \mathrm{N}$, etc.) on the diversity and activity of microbial communities in diverse environments (Miller et al. 2009; Lawes et al. 2016), including AMD (Kuang et al. 2013, Volant et al. 2014). The development of these distinct bacterial communities resulted in difference in terms of pollution removal efficiency and of composition of the biogenic precipitates formed during incubation.

In batch incubated at $20^{\circ} \mathrm{C}$, bacterial community was largely dominated by OTUs related to the ironoxidizing Gallionella (92\% of total sequences), widely represented in iron-rich environments including AMD (Bruneel et al. 2006; Volant et al. 2014). Dominance of this bacterial group was associated with complete Fe(II) oxidation, and a low As(III) oxidation activity. This is in accordance with the formation of iron- and As(III)-rich precipitates in the T20 batch.

\section{Effect of nutrient supply on bacterial communities and on pollution attenuation}

In agreement with other studies (Sipura et al. 2005; Leflaive et al. 2008), bacterial cell concentration increased in nutrient amended batch. The supply of yeast extract stimulated the development of mixotrophic Thiomonas. As a result, As(III) oxidation was stimulated and arsenic removal from the dissolved phase was complete, both at 20 and $35^{\circ} \mathrm{C}$. Members of the Thiomonas genus include aioA-carrying AsOB commonly found in AMD-impacted environments (Bruneel et al. 2003; Battaglia-Brunet et al. 2006; Bryan et al. 2009). Conversely, the rate of iron oxidation was partially inhibited in nutrient amended batch incubated at $20^{\circ} \mathrm{C}$ despite the presence of FeOB like-Gallionella (10\% of total sequences). Gallionella spp. can grow autotrophically (Emerson et al. 2013) or mixotrophically (Hallbeck and Pedersen 1991). We can hypothesize that supply of yeast extract (representing a diverse source of carbon and nitrogen) resulted in the inhibition of growth or activity of FeOB 
Gallionella to the advantage of heterotrophic and mixotrophic bacteria such as Acidocella, Thiomonas, Rhodanobacter and Arthrobacter. Among them, Acidocella, which is commonly found in iron rich environments including AMD (Sheng et al. 2016), was predominant (52\% of total sequences). Acidocella is an iron-reducing bacteria (FeRB), able to use $\mathrm{Fe}(\mathrm{III})$ as the sole electron acceptor under anaerobic or oxygen limiting conditions (Coupland and Johnson 2008; Lu et al. 2010). Interestingly, the inhibitive effect of yeast extract on iron oxidation was counterbalanced when the batch were incubated at $35^{\circ} \mathrm{C}$. In that case, $\mathrm{Fe}(\mathrm{II})$ oxidation was delayed but complete. This efficient Fe removal in T35Y batch was possibly due the increasing proportion of bacteria related to the Ferritrophicum genus which include iron-oxidizing bacteria (Gonzalez-Toril et al. 2011; Hedrich et al. 2011). The possible involvement of other group favored in T35Y including the moderately acidophilic and obligate heterotroph Acidicapsa genus (Kulichevskaya et al. 2012) may not be excluded and would require further investigation.

\section{Effect of temperature on bacterial communities and on pollution attenuation}

Enhanced arsenic oxidation and removal at $35^{\circ} \mathrm{C}$ compared to $20^{\circ} \mathrm{C}$ was not associated with an increase of biomass. This suggests that bacterial activity was boosted rather than bacterial growth. Another possible explanation is the preferential development at $35^{\circ} \mathrm{C}$ of populations efficient for arsenic removal. The stimulation of $\mathrm{As}(\mathrm{III})$ oxidation at $35^{\circ} \mathrm{C}$ was associated with the large dominance of Thiomonas genus (61\% of total sequences) and a higher proportion of aioA genes. Several Thiomonas strains exhibit an optimum growth temperature of 30$37^{\circ} \mathrm{C}$ (Kelly et al. 2007; Panda et al. 2009). These findings highlight the importance of temperature on both the abundance and activity of AsOB like-Thiomonas, as shown for other AsOB (Ito et al. 2012; Debiec et al. 2017). The second more abundant OTU was affiliated to the Ferritrophicum genus (8\% of total sequences). The cooccurrence of these two bacterial groups in batch incubated at $35^{\circ} \mathrm{C}$ can be linked to the formation of iron- and $\mathrm{As}(\mathrm{V})$-rich precipitates.

Environmental significance

The biogenic precipitates formed in batch without nutrient exhibited an As/Fe ratio ranging between 0.10.2. Similar ranges (0.15-0.2) were obtained in a continuous flow reactor treating Carnoulès AMD water (Fernandez-Rojo et al. 2017). These As/Fe ratios are lower than those observed in situ in the Reigous streambed (0.4-0.7, Morin et al. 2003; Egal et al. 2010; Maillot et al. 2013). In the present batch experiments, conditions that favored As oxidation while limiting Fe oxidation (T20Y) led to As/Fe ratio in the precipitate similar to field values. This suggests that As oxidation is probably stimulated in the field, and Fe oxidation slowed down, compared to laboratory conditions. The reason for such difference might be related to the inability of some microorganisms to develop or maintain their activity under laboratory conditions.

Seasonal variations of As speciation were observed in Carnoulès AMD (Morin et al. 2003; Egal et al. 2010) with the preferential formation of As(III)-rich precipitates during the coldest season, mainly in the form of tooeleite. Conversely, during summer, $\mathrm{As}(\mathrm{V})$ dominates in the amorphous ferric arsenate form. These field observations are in agreement with our results that clearly revealed a positive effect of higher temperature on microbially mediated As(III) oxidation. As a consequence, in case of an in situ biological treatment, contrasted 
347 or the season. The formation of stable As(V)-rich biogenic precipitates might be favored at temperatures higher 348 than $20^{\circ} \mathrm{C}$.

Nutrient supply favored the formation of $\mathrm{As}(\mathrm{V})$ rich precipitates, which are preferred to As(III) solid phases in AMD treatment process due to their stability upon storage (Palfy et al. 1999). However, the stimulation

351 of iron-reducing bacteria Acidocella may result in the remobilization of arsenic if conditions became reducing or in anoxic micro niches (Héry et al. 2014). For this reason, possible use of organic matter amendement in aerobic AMD treatment has to be carefully considered.

Our results evidenced clear links between taxonomic composition of bacterial community, abundance of aioA gene, and iron and arsenic oxidation and removal from AMD water. They give new insights into the regulation by temperature and nutrients of microbially mediated processes involved in natural pollution attenuation. Studies focusing on single strains did not take into account the metabolic and functional diversity present in natural ecosystems. On the contrary our study based on a complex indigenous community integrates all the differential effects the applied treatment may have on the different bacterial populations co-existing among the community. Then, our approach gives a more representative picture of what could occur in situ under temperature or nutrient status changing conditions than previous studies on single Fe(II)- or As(III)-oxidizing bacterial strains. 
364 This work was supported by the Agence Nationale de Recherche (ANR) as part of ANR IngECOST-DMA project 365 (ANR-13-ECOT-0009) and the OSU OREME. It benefited from the technical facilities of Get-PlaGe platform 366 (http://get.genotoul.fr/), Montpellier RIO Imaging microscopy platform (https://www.mri.cnrs.fr/) and the AETE367 ISO Platform (OSU REME, Université de Montpellier).

\section{Compliance with Ethical Standards}

369 Conflict of Interest: The authors declare they have no conflict of interest.

370 Ethical approval: This article does not contain any studies with human participants or animals performed by any 371 of the authors. 


\section{References}

Ahoranta SH, Kokko ME, Papirio S, Özkaya B, Puhakka JA (2016) Arsenic removal from acidic solutions with biogenic ferric precipitates. J Hazard Mater 306:124-132. doi: 10.1016/j.jhazmat.2015.12.012

Asta MP, Ayora C, Román-Ross G, Cama J, Acero P, Gault AG, Charnock JM, Bardelli F (2010) Natural attenuation of arsenic in the Tinto Santa Rosa acid stream (Iberian Pyritic Belt, SW Spain): The role of iron precipitates. Chem Geol 271:1-12. doi: 10.1016/j.chemgeo.2009.12.005

Barret M, Briand M, Bonneau S, Préveaux A, Valière S, Bouchez O, Hunault G, Simoneau P, Jacquesa MA (2015) Emergence shapes the structure of the seed microbiota. Appl Environ Microbiol 81:1257-1266. doi: 10.1128/AEM.03722-14

Battaglia-Brunet F, Dictor MC, Garrido F, Crouzet C, Morin D, Dekeyser K, Clarens M, Baranger P (2002) An arsenic ( III )-oxidizing bacterial population: selection, characterization, and performance in reactors. J Appl Microbiol 93:656-667.

Battaglia-Brunet F, Joulian C, Garrido F, Dictor MC, Morin D, Coupland K, Barrie Johnson D, Hallberg KB, Baranger P (2006) Oxidation of arsenite by Thiomonas strains and characterization of Thiomonas arsenivorans sp. nov. Antonie van Leeuwenhoek, 89:99-108. doi: 10.1007/s10482-005-9013-2

Bruneel O, Duran R, Casiot C, Elbaz-Poulichet F, Personné JC (2006) Diversity of microorganisms in Fe-As-rich acid mine drainage waters of Carnoulès, France. Appl Environ Microbiol 72:551-556. doi: 10.1128/AEM.72.1.551-556.2006

Bruneel O, Personné JC, Casiot C, Leblanc M, Elbaz-Poulichet F, Mahler BJ, Le Flèche A, Grimont PAD (2003) Mediation of arsenic oxidation by Thiomonas sp. in acid-mine drainage (Carnoulès, France). J Appl Microbiol 95:492-499. doi: 10.1046/j.1365-2672.2003.02004.x

Bryan CG, Marchal M, Battaglia-Brunet F, Kugler V, Lemaitre-Guillier C, Lièvremont D, Bertin PN, ArsènePloetze F (2009) Carbon and arsenic metabolism in Thiomonas strains: differences revealed diverse adaptation processes. BMC Microbiol 9:127. doi: 10.1186/1471-2180-9-127

Campbell KM, Kirk Nordstrom D (2014) Arsenic speciation and sorption in natural environments. Rev Mineral Geochem 79:185-216. doi: 10.1128/9781555817510.ch5

Casiot C, Leblanc M, Bruneel O (2003a) Geochemical Processes Controlling the Formation of As-rich waters within a Tailings Impoundment ( Carnoulès, France). Aquat Geochem 9:273-290. doi: 10.1023/B:AQUA.0000028985.07557.39

Casiot C, Morin G, Juillot F, Bruneel O, Personné JC, Leblanc M, Duquesne K, Bonnefoy V, Elbaz-Poulichet F (2003b) Bacterial immobilization and oxidation of arsenic in acid mine drainage (Carnoulès creek, France). Water Res 37:2929-2936. doi: 10.1016/S0043-1354(03)00080-0

Cheng H, Hu Y, Luo J, Xu B, Zhao J (2009) Geochemical processes controlling fate and transport of arsenic in acid mine drainage (AMD) and natural systems. J Hazard Mater 165:13-26. doi: 10.1016/j.jhazmat.2008.10.070

Coupland K, Johnson DB (2008) Evidence that the potential for dissimilatory ferric iron reduction is widespread among acidophilic heterotrophic bacteria. FEMS Microbiol Lett 279:30-35. doi: 10.1111/j.15746968.2007.00998.x

Debiec K, Krzysztoforski J, Uhrynowski W, Sklodowska A, Drewniak L (2017) Kinetics of arsenite oxidation by Sinorhizobium sp. M14 under changing environmental conditions. Int Biodeterior Biodegradation 119:476- 
Dopson M, Halinen A-K, Rahunen N, Ozkaya B, Sahinkaya E, Kaksonen AH, Lindström EB, Puhakka JA (2006) Mineral and Iron Oxidation at Low Temperatures by Pure and Mixed Cultures of Acidophilic Microorganisms. Biotechnol Bioeng 97:1205-1215. doi: 10.1002/bit.21312

Duquesne K, Lebrun S, Casiot C, Bruneel O, Personné JC, Leblanc M, Morin G, Bonnefoy V (2003) Immobilization of Arsenite and Ferric Iron by Acidithiobacillus ferrooxidans and Its Relevance to Acid Mine Drainage. Appl Environ Microbiol 69:6165-6173. doi: 10.1128/AEM.69.10.6165

Edgar RC, Haas BJ, Clemente JC, Quince C, Knight R (2011) UCHIME improves sensitivity and speed of chimera detection. Bioinformatics 27:2194-2200. doi: 10.1093/bioinformatics/btr381

Egal M, Casiot C, Morin G, Elbaz-Poulichet F, Cordier MA, Bruneel O (2010) An updated insight into the natural attenuation of As concentrations in Reigous Creek (southern France). Appl Geochem 25:1949-1957. doi: 10.1016/j.apgeochem.2010.10.012

Egal M, Casiot C, Morin G, Parmentier M, Bruneel O, Lebrun S, Elbaz-Poulichet F (2009) Kinetic control on the formation of tooeleite, schwertmannite and jarosite by Acidithiobacillus ferrooxidans strains in an As(III)rich acid mine water. Chem Geol 265:432-441. doi: 10.1016/j.chemgeo.2009.05.008

Emerson D, Field EK, Chertkov O, Davenport KW, Goodwin L, Munk C, Nolan M, Woyke T (2013) Comparative genomics of freshwater Fe-oxidizing bacteria: Implications for physiology, ecology, and systematics. Front Microbiol 4:1-17. doi: 10.3389/fmicb.2013.00254

Fernandez-Rojo L, Héry M, Le pape P, Braungardt C, Desoeuvre A, Torres E, Tardy V, Resongles E, Laroche E, Delpoux S, Joulian C, Battaglia-Brunet F, Boisson J, Grapin G, Morin G, Casiot C (2017) Biological attenuation of arsenic and iron in a continuous flow bioreactor treating acid mine drainage (AMD). Water Res 123:594-606. doi: 10.1016/j.watres.2017.06.059

Fukushi K, Sasaki M, Sato T, Yanase N, Amano H, Ikeda H (2003) A natural attenuation of arsenic in drainage from an abandoned arsenic mine dump. Appl Geochem 18:1267-1278. doi: 10.1016/S0883-2927(03)000118

Garcia-Dominguez E, Mumford A, Rhine ED, Paschal A, Young LY (2008) Novel autotrophic arsenite-oxidizing bacteria isolated from soil and sediments. FEMS Microbiol Ecol 66:401-410. doi: 10.1111/j.15746941.2008.00569.x

Gonzalez-Toril E, Aguilera A, Souza-Egipsy V, Pamo EL, Espana JS, Amils R (2011) Geomicrobiology of La Zarza-Perrunal acid mine effluent (Iberian Pyritic Belt, Spain). Appl Environ Microbiol 77:2685-2694. doi: 10.1128/AEM.02459-10

Hallbeck L, Pedersen K (1991) Autotrophic and mixotrophic growth of Gallionella ferruginea. J Gen Microbiol 137:2657-2661. doi: 10.1099/00221287-137-11-2657

Hedrich S, Schlomann M, Johnson DB (2011) The iron-oxidizing proteobacteria. Microbiology 157:1551-1564.

Héry M, Casiot C, Resongles E, Gallice Z, Bruneel O, Desoeuvre A, Delpoux S (2014) Release of arsenite, arsenate and methyl-arsenic species from streambed sediment affected by acid mine drainage: A microcosm study. Environ Chem 11:514-524. doi: 10.1071/EN13225

Hibbing ME, Fuqua C, Parsek MR, Peterson SB (2010) Bacterial competition: surviving and thriving in the microbial jungle. Natl Rev Microbiol 8:15-25. doi: 10.1038/nrmicro2259.Bacterial

Hug SJ, Leupin OX (2003) Iron-catalyzed oxidation of arsenic (III) by oxygen and by hydrogen peroxide: $\mathrm{pH}-$ 
dependent formation of oxidants in the Fenton reaction. Environ Sci Technol 37:2734-2742.

454

455

456

457

458

459

460

461

462

463

464

465

466

467

468

469

470

471

472

473

474

475

476

477

478

479

480

481

482

483

484

485

486

487

488

489

490

491

492

Ito A, Miura JI, Ishikawa N, Umita T (2012) Biological oxidation of arsenite in synthetic groundwater using immobilised bacteria. Water Res 46:4825-4831. doi: 10.1016/j.watres.2012.06.013

Johnson DB, Hallberg KB (2005) Acid mine drainage remediation options: A review. Sci Total Environ 338:314. doi: 10.1016/j.scitotenv.2004.09.002

Kelly DP, Uchino Y, Huber H, Amils R, Wood AP (2007) Reassessment of the phylogenetic relationships of Thiomonas cuprina. Int J Syst Evol Microbiol 57:2720-2724. doi: 10.1099/ijs.0.65537-0

Kim D-J, Pradhan D, Park K-H, Ahn J-G, Lee S-W (2008) Effect of pH and Temperature on Iron Oxidation by Mesophilic Mixed Iron Oxidizing Microflora. Mater Trans 49:2389-2393. doi: 10.2320/matertrans.MER2008051

Koskella B, Vos M (2015) Adaptation in natural microbial populations. Annu Rev Ecol Evol Syst 46:503-522. doi: 10.1146/annurev-ecolsys-112414-054458

Kuang J-L, Huang L-N, Chen L-X, Hua Z-S, Li S-J, Hu M, Li J-T, Shu W-S (2013) Contemporary environmental variation determines microbial diversity patterns in acid mine drainage. ISME J 7:1038-50. doi: 10.1038/ismej.2012.139

Kulichevskaya IS, Kostina LA, Valášková V, Rijpstra WIC, Sinninghe Damsté JS, de Boer W, Dedysh SN (2012) Acidicapsa borealis gen. nov., sp. nov. and Acidicapsa ligni sp. nov., subdivision 1 Acidobacteria from Sphagnum peat and decaying wood. Int J Syst Evol Microbiol 62, 1512-1520. doi: 10.1099/ijs.0.034819-0

Lawes JC, Neilan BA, Brown MV, Clark GF, Johnston EL (2016) Elevated nutrients change bacterial community composition and connectivity: high throughput sequencing of young marine biofilms. Biofouling 32:57-69. doi: 10.1080/08927014.2015.1126581

Leflaive J, Danger M, Lacroix G, Lyautey E, Oumarou C, Ten-Hage L (2008) Nutrient effects on the genetic and functional diversity of aquatic bacterial communities. FEMS Microbiol Ecol 66:379-390. doi: 10.1111/j.1574-6941.2008.00593.x

Lozupone C, Knight R (2005) UniFrac : a New Phylogenetic Method for Comparing Microbial Communities. Appl Environ Microbiol 71:8228-8235. doi: 10.1128/AEM.71.12.8228

Lu S, Gischkat S, Reiche M, Akob DM, Hallberg KB, Küsel K (2010) Ecophysiology of Fe-cycling bacteria in acidic sediments. Appl Environ Microbiol 76:8174-8183. doi: 10.1128/AEM.01931-10

Lunau M, Lemke A, Walther K, Martens-Habbena W, Simon M (2005) An improved method for counting bacteria from sediments and turbid environments by epifluorescence microscopy. Environ Microbiol 7:961-968. doi: 10.1111/j.1462-2920.2005.00767.x

Magoc T, Salzberg SL (2011) FLASH: Fast length adjustment of short reads to improve genome assemblies. Bioinformatics 27:2957-2963. doi: 10.1093/bioinformatics/btr507

Maillot F, Morin G, Juillot F, Bruneel O, Casiot C, Ona-Nguema G, Wang Y, Lebrun S, Aubry E, Vlaic G, Brown GE (2013) Structure and reactivity of As(III)- and As(V)-rich schwertmannites and amorphous ferric arsenate sulfate from the Carnoulès acid mine drainage, France: Comparison with biotic and abiotic model compounds and implications for As remediation. Geochim Cosmochim Acta 104:310-329. doi: 10.1016/j.gca.2012.11.016

Méndez-García C, Peláez AI, Mesa V, Sánchez J, Golyshina OV, Ferrer M (2015) Microbial diversity and metabolic networks in acid mine drainage habitats. Front Microbiol 6:475. doi: 10.3389/fmicb.2015.00475 
Miller SR, Strong AL, Jones KL, Ungerer MC (2009) Bar-coded pyrosequencing reveals shared bacterial community properties along the temperature gradients of two alkaline hot springs in Yellowstone National Park. Appl Environ Microbiol 75:4565-4572. doi: 10.1128/AEM.02792-08

Mitsunobu S, Hamanura N, Kataoka T, Shiraishi F (2013) Arsenic attenuation in geothermal streamwater coupled with biogenic arsenic(III) oxidation. Appl Geochemistry 35:154-160. doi: 10.1016/j.apgeochem.2013.04.005

Morin G, Juillot F, Casiot C, Bruneel O, Personné JC, Elbaz-Poulichet F, Leblanc M, Ildefonse P, Calas G (2003) Bacterial formation of tooeleite and Mixed Arsenic(III) or Arsenic(V) - Iron(III) gels in the carnoulès acid mine drainage, France. A XANES, XRD, and SEM study. Environ Sci Technol 37:1705-1712. doi: $10.1021 / \mathrm{es} 025688 \mathrm{p}$

Nordstrom DK, Alpers CN (1999) Negative pH, efflorescent mineralogy, and consequences for environmental restoration at the Iron Mountain Superfund site, California. Proc Natl Acad Sci U S A 96:3455-3462. doi: 10.1073/pnas.96.7.3455

Okie JG, Van Horn DJ, Storch D, Barrett JE, Gooseff MN, Kopsova L, Takacs-Vesbach CD (2015) Niche and metabolic principles explain patterns of diversity and distribution: theory and a case study with soil bacterial communities. Proc R Soc B Biol Sci 282:20142630. doi: 10.1098/rspb.2014.2630

Paikaray S (2015) Arsenic Geochemistry of Acid Mine Drainage. Mine Water Environ 34:181-196. doi: $10.1007 / \mathrm{s} 10230-014-0286-4$

Palfy P, Vircikova E, Molnar L (1999) Processing of arsenic waste by precipitation and solidification. Waste Manag 19:55-59. doi: 10.1016/S0956-053X(99)00014-8

Panda SK, Jyoti V, Bhadra B, Nayak KC, Shivaji S, Rainey FA, Das SK (2009) Thiomonas bhubaneswarensis sp. nov., an obligately mixotrophic, moderately thermophilic, thiosulfate-oxidizing bacterium. Int J Syst Evol Microbiol 59:2171-2175. doi: 10.1099/ijs.0.007120-0

Puspita ID, Kamagata Y, Tanaka M, Asano K, Nakatsu CH (2012) Are Uncultivated Bacteria Really Uncultivable? Microbes Environ. 27: 356-366. doi:10.1264/jsme2.ME12092

Quéméneur M, Cébron A, Billard P, Battaglia-Brunet F, Garrido F, Leyval C, Joulian C (2010) Population structure and abundance of arsenite-oxidizing bacteria along an arsenic pollution gradient in waters of the upper isle river basin, France. Appl Environ Microbiol 76:4566-4570. doi: 10.1128/AEM.03104-09

Resongles E, Le Pape P, Fernandez-Rojo L, Morin G, Delpoux S, Brest J, Guo S, Casiot C (2016) Routine determination of inorganic arsenic speciation in precipitates from acid mine drainage using orthophosphoric acid extraction followed by HPLC-ICP-MS. Anal Methods 8:7420-7426. doi: 10.1039/c6ay02084d

Rodier J (1996) L'analyse de l'eau, eaux résiduaires, eau de mer, $8^{\text {ème }}$ Edition. Dénod Paris

Santini JM, Sly LI, Schnagl RD, Macy JM (2000) A new chemolithoautotrophic arsenite-oxidizing bacterium isolated from a gold mine: Phylogenetic, physiological, and preliminary biochemical studies. Appl Environ Microbiol 66:92-97. doi: 10.1128/aem.66.1.92-97.2000

Schloss PD, Westcott SL, Ryabin T, Hall JR, Hartmann M, Hollister EB, Lesniewski RA, Oakley BB, Parks DH, Robinson CJ, Sahl JW, Stres B, Thallinger GG, Van Horn DJ, Weber CF (2009) Introducing mothur: Opensource, platform-independent, community-supported software for describing and comparing microbial communities. Appl Environ Microbiol 75:7537-7541. doi: 10.1128/AEM.01541-09 
Sheng Y, Bibby K, Grettenberger C, Kaley B, Macalady JL, Wang G, Burgos WD (2016) Geochemical and temporal influences on the enrichment of acidophilic iron-oxidizing bacterial communities. Appl Environ Microbiol 82:3611-3621. doi: 10.1128/AEM.00917-16

Sipura J, Haukka K, Helminen H, Lagus A, Suomela J, Sivonen K (2005) Effect of nutrient enrichment on bacterioplankton biomass and community composition in mesocosms in the Archipelago Sea, northern Baltic. J Plankton Res 27:1261-1272. doi: 10.1093/plankt/fbi092

Slyemi D, Moinier D, Brochier-Armanet C, Bonnefoy V, Johnson DB (2011) Characteristics of a phylogenetically ambiguous, arsenic-oxidizing Thiomonas sp., Thiomonas arsenitoxydans strain 3AsT sp. nov. Arch Microbiol 193:439-449. doi: 10.1007/s00203-011-0684-y

Volant A, Bruneel O, Desoeuvre A, Héry M, Casiot C, Bru N, Delpoux S, Fahy A, Javerliat F, Bouchez O, Duran R, Bertin PN, Elbaz-Poulichet F, Lauga B (2014) Diversity and spatiotemporal dynamics of bacterial communities: physicochemical and others drivers along an acid mine drainage. FEMS Microbiol Ecol 90:247-263. doi: 10.1111/1574-6941.12394

Wang Q, Garrity GM, Tiedje JM, Cole JR (2007) Naïve Bayesian classifier for rapid assignment of rRNA sequences into the new bacterial taxonomy. Appl Environ Microbiol 73:5261-5267. doi: 10.1128/AEM.00062-07

Wang Y, Qian PY (2009) Conservative fragments in bacterial 16S rRNA genes and primer design for 16S ribosomal DNA amplicons in metagenomic studies. PLoS One 4 (10):e70401. doi: 


\section{List of figure legends}

554 Fig. 1 Bacterial biomass in abiotic $(n=5)$ and biotic $(n=8)$ batch experiment at the beginning (T0) and at the end 555 of the experiment (T8). Symbols inside boxplots represent the treatments applied (T20: batch incubated at $20^{\circ} \mathrm{C}$; 556 T35: batch incubated at $35^{\circ} \mathrm{C}$; T20Y: batch incubated at $20^{\circ} \mathrm{C}$ with nutrients; T35Y: batch incubated at $35^{\circ} \mathrm{C}$ with 557 nutrients). Different letters in brackets indicate statistically significant differences $(\mathrm{P}<0.05)$ according to Kruskal558 Wallis test.

559 Fig. 2 Evolution of dissolved Fe(II) (A), dissolved As(III) (B) and precipitated Fe concentrations (C) during 560 incubation time for abiotic (empty symbols) and biotic (lines with full symbols) batch experiment for all treatments 561 (T20: batch incubated at $20^{\circ} \mathrm{C}$; T35: batch incubated at $35^{\circ} \mathrm{C}$; T20Y: batch incubated at $20^{\circ} \mathrm{C}$ with nutrients; 35 Y: 562 batch incubated at $35^{\circ} \mathrm{C}$ with nutrients).

563 Fig. 3 Proportion of Fe(II) (A) and As(III) (B) oxidized after 8 days of incubation relatively to Fe(II) and As(III) 564 concentration in the Carnoulès $\mathrm{AMD}$ at $\mathrm{t}_{0}$ for both abiotic and biotic treatments (T20: batch incubated at $20^{\circ} \mathrm{C}$; $565 \mathrm{~T} 35$ : batch incubated at $35^{\circ} \mathrm{C}$; T20Y: batch incubated at $20^{\circ} \mathrm{C}$ with nutrients; $\mathrm{T} 35 \mathrm{Y}$ : batch incubated at $35^{\circ} \mathrm{C}$ with 566 nutrients). For biotic treatments, values with different letters differ significantly $(\mathrm{P}<0.05)$ according to Fisher 567 test.

568 Fig. 4 Non-metric multi-dimensional scaling (NMDS) ordination plot derived from weighted pairwise Unifrac 569 distances for bacterial communities for each treatment (S: Source; T20: batch incubated at $20^{\circ} \mathrm{C}$; T35: batch 570 incubated at $35^{\circ} \mathrm{C}$; T20Y: batch incubated at $20^{\circ} \mathrm{C}$ with nutrients; T35Y: batch incubated at $35^{\circ} \mathrm{C}$ with nutrients).

571 Stress values for ordination plot were $<0.2$ which indicates that these data were well-represented by the two 572 dimensional representation.

573 Fig. 5 Relative abundance of bacterial genera in the water collected at the Reigous stream and in the batch at the 574 end of the incubations. All the analyses were performed in triplicates (S: Source; T20: batch incubated at $20^{\circ} \mathrm{C}$; $575 \mathrm{~T} 35$ : batch incubated at $35^{\circ} \mathrm{C}$; T20Y: batch incubated at $20^{\circ} \mathrm{C}$ with nutrients; $\mathrm{T} 35 \mathrm{Y}$ : batch incubated at $35^{\circ} \mathrm{C}$ with 576 nutrients). Cluster tree represent phylogenetic community distance based on the OTU composition. Other groups 577 represent the phylogenetic groups (genus) with a relative abundance $<1 \%$ calculated on the whole dataset. 578 Asterisks represent phylogenetic group affiliated to higher taxonomic levels.

579 Fig. 6 Quantification of aioA genes in the Reigous water and in the biotic batch at the end of the incubations ( $\mathrm{n}=3$ ) 580 with S: Source corresponding to water collected at the Reigous stream used in batch experiments; T20: batch 581 incubated at $20^{\circ} \mathrm{C}$; T35: batch incubated at $35^{\circ} \mathrm{C}$; T20Y: batch incubated at $20^{\circ} \mathrm{C}$ with nutrients; T35Y: batch 582 incubated at $35^{\circ} \mathrm{C}$ with nutrients. Letters in brackets indicate significant differences between treatments, according 583 to Kruskal-Wallis test $(\mathrm{P}<0.05)$. 